\title{
RESEARCHPAPER
}

\section{Evaluation of resistance for early blight caused by Alternaria solani (Ellis and Martin) Sorauer in tomato}

\author{
S. M. YADAV ${ }^{1}$, VINEETA SINGH ${ }^{1}$, MAJOR SINGH ${ }^{2}$, LAXMAN PRASAD BALAI ${ }^{3}$ AND RAMESH \\ CHAND $^{1}$ \\ ${ }^{1}$ Department of Mycology and Plant Pathology, Institute of Agricultural Sciences, Banaras Hindu University, \\ VARANASI (U.P.) INDIA \\ ${ }^{2}$ Division of Crop Improvement, Indian Institute of Vegetable Research, VARANASI (U.P.) INDIA \\ ${ }^{3}$ ICAR, CAZRI, KrishiVigyan Kendra, PALI (RAJASTHAN) INDIA \\ Email : sanwar1785@gmail.com
}

Article Info : Received : 03.03.2017; Revised : 07.08.2017; Accepted : 04.09.2017

A trial was conducted during Rabi season 2011-2012 under field conditions for phenotyping of germplasm under natural conditions that have been developed for resistance against early blight of tomato caused by Alternaria solani. Field studies showed significant variation among all tested germplasm lines with respect to early blight disease assessment. Under field conditions the natural disease severity was scored on a five-point scale (0-5). The per cent disease index (PDI) and area under disease progress curve (AUDPC) value were calculated on the basis of data recorded. The mean AUDPC value in resistant (206 lines); moderately resistant (223 lines); moderately susceptible (129 lines) and susceptible (143 lines) tomato lines ranged between 102.00 to 447.25 ; 447.26 to $792.50 ; 792.51$ to 1137.75 and 1137.76 to 1483.00 , respectively.

Key words : Alternaria solani, Tomato, Natural inoculums, Phenotyping, Resistant, AUDPC

How to cite this paper: Yadav, S.M., Singh, Vineeta, Singh, Major, Balai, Laxman Prasad and Chand, Ramesh (2017). Evaluation of resistance for early blight caused by Alternaria solani (Ellis and Martin) Sorauer in tomato. Asian J. Bio. Sci., 12 (2) : 87-99.DOI : 10.15740/HAS/AJBS/ 12.2/87-99. 